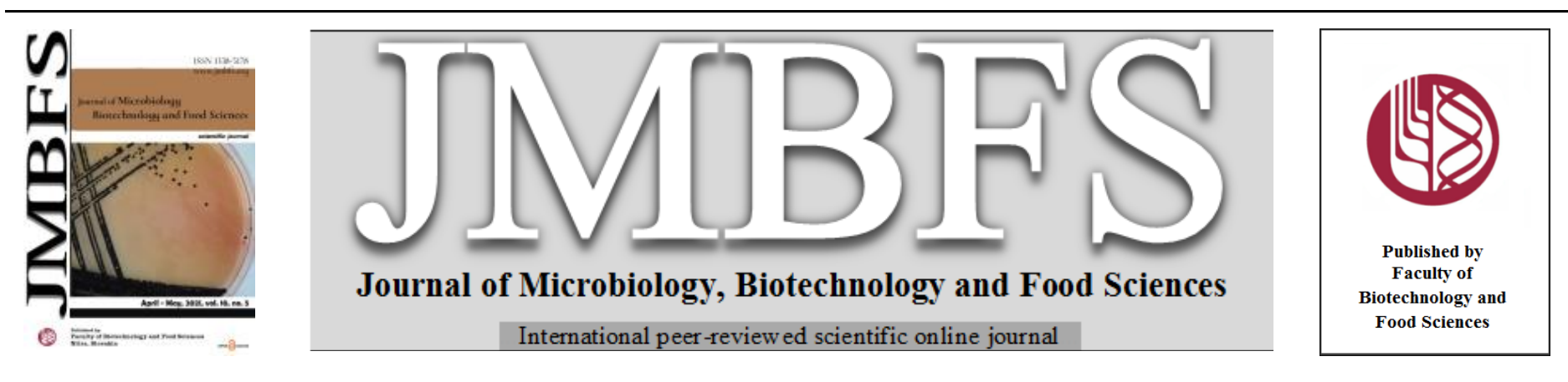

\title{
PHENOLIC CONTENT AND ANTIOXIDANT ACTIVITY OF SLOVAK VARIETAL WINES OF MUSCAT TYPE
}

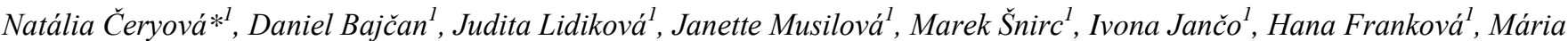 \\ Bláhová ${ }^{2}$
}

\begin{abstract}
Address(es): Ing. Natália Čeryová,
${ }^{1}$ Slovak University of Agriculture in Nitra, Faculty of Biotechnology and Food Sciences, Department of Chemistry, Tr. A. Hlinku 2, 94976 Nitra, Slovak Republic. ${ }^{2}$ Economic University in Bratislava, Faculty of Applied Languages, Department of Intercultural Communication, Dolnozemská cesta 1, 852 35, Bratislava, Slovak Republic.
\end{abstract}

*Corresponding author: nceryova@gmail.com

https://doi.org/10.15414/jmbfs.4292

\section{ARTICLE INFO}

Received 7. 10. 2020

Revised 13. 12. 2020

Accepted 17. 12. 2020

Published 1. 4. 2021

Regular article open $\partial_{\text {ACCESS }}$

\begin{abstract}
Grapes and wine are important sources of antioxidants in human diet. Phenolic substances contained in grapevine berries belong to an important group of natural substances that get into wine in the process of wine making. Polyphenols and flavonoids are primarily accountable for the colour and taste of the wine, they affect the perception of bitterness and acerbity. They also have antioxidant properties, thus have a positive effect on human health. Health benefits of polyphenolic substances from wine may be associated with a wide range of biological processes. Thanks to the development of modern analytical methods, wine is constantly being researched in terms of the content of antioxidants, and its importance to human health. Sixteen Slovak white wines of Muscat type produced in different geographical regions were analysed in this study. The object of this work was to determine total polyphenol content and total flavonoid content, and to evaluate antioxidant effects of quality wines of Muscat varieties produced in Slovakia. Antioxidant activity, total polyphenol content, and total flavonoid content of particular wines is described in the study. Studied characteristics were analysed by UV-VIS spectrometry method. Muscat wines showed weak to high antioxidant activity, ranging from $25.2 \%$ inhibition of DPPH to 67.7\% inhibition of DPPH. Average antioxidant activity was 38.7\% inhibition of DPPH. Total polyphenol content in the Muscat type varietal wines varied from $262.1 \mathrm{GAE} . \mathrm{L}^{-1}$ to $568.3 \mathrm{GAE} . \mathrm{L}^{-1}$. Average total polyphenol content was $382.13 \mathrm{GAE} . \mathrm{L}^{-1}$. The content of total flavonoids in Muscat type varietal wines ranged from $24.8 \mathrm{mg} \mathrm{CE} . \mathrm{L}^{-1}$ to $169.1 \mathrm{mg}$ CE. $\mathrm{L}^{-1}$. Average total flavonoid content was $100.5 \mathrm{mg}$ CE.L. ${ }^{-1}$.
\end{abstract}

Keywords: wine, muscat, polyphenols, flavonoids, antioxidants

\section{INTRODUCTION}

Wine is a complex mixture obtained by complete or partial fermentation of grape must (Cheynier, 2010). It contains more than a thousand substances, some of which have not been precisely analysed yet. Most of these substances come from berries of the grape vine, others are formed during processing. Some substances are partially or completely degraded during processing (Dominé, 2005). Wines owe their colour and structure to phenolic compounds. The concentration of phenolic substances increases during the ripening of berries, and these substances subsequently give wine its character and quality. In white wines, with gentle processing of grapes, their content changes up to $250 \mathrm{mg} \cdot \mathrm{L}^{-1}$. In red wines, content of phenolic compounds is up to $450 \mathrm{mg} . \mathrm{L}^{-1}$ (Michlovský, 2014). Phenols are compounds of great importance for viticulture and winemaking. There is a significant difference between varieties of red and white wines in the content of phenolic substances, and their composition in grapes and wine (Pavloušek, 2011). Phenolic substances are significant to both white and red wines. In white wines, higher levels of polyphenols are mostly undesirable, as they can contribute to excessive bitterness and also to the tendency of the wine to brown when it is exposed to air. In red wines, they contribute to the bitterness, astringency, and other organoleptic properties, such as colour of the wine. (Waterhouse, 2003). These substances affect the taste and appearance of the wine, in particular colour, bitterness, acerbity, absorption of oxygen and the aging process of the must or the wine (Steidl, 2010). The extraction of phenolic compounds in the process of winemaking has important effect on the colour and taste of the wine (Jiang, Zhang, 2012).

The phenolic composition of wine is affected by the composition of grapes, which is influenced by many aspects, such as cultivar, viticultural practices and environmental conditions, and various techniques, and several reactions occurring during the procces of wine making (Sacchi, Bisson, Adams, 2005) Viticultural practices, such as canopy management, yield regulation, irrigation, and harvest time, can influence the content and composition of different flavonoids, e.g. anthocyanins, proanthocyanidins and flavonols (Downey, Dokoozlian, Krstic, 2006). Dumitriu (2015) proved that nanomaterials could decrease the total phenolic content in wines.

Vermerris and Nicholson (2006) define phenolic substances as compounds having one or more hydroxyl groups attached directly to the aromatic ring formed by benzene. They comprise of approximately 8000 compounds (Kabera $\boldsymbol{e t}$ al. 2014). There is no consensus regarding how phenolic compounds should be classified. Most classifications of phenolics are based on their chemical structure. In this sense, we can classify them in four different ways: 1. Flavonoids ad nonflavonoids, 2 . by the amount of aromatic rings, 3 . by the carbon skeleton, and 4 . by the basic chemical structure, which is most widely used (Santana-Gálvez, Jacobo-Velázquez, 2018). Phenolic compounds mainly identified in wine are hydroxycinnamic and hydroxybenzoic acids, flavanols, flavonols, flavones, flavanonols, stilbenes, and anthocyanins (Monagas, 2005).

From a nutritional point of view, grapes and wine are good food sources of phenolic compounds (Cueva et al., 2017). The most significant phenolics found in the human nutrition are phenolic acids, flavonoids, and tannins (Vuolo, Lima, Junior, 2019).

Lately, dietary polyphenols have drawn attention because of their ability to scavenge free radicals, chelate metal and regulate digestive enzymes, (Rasouli, Farzaei, Khodarahmi, 2017). A number of health benefits have been linked to phenolic compounds, besides antioxidant effects. Studies shown, that polyphenols also have anti-inflammatory effect, anti-hypertensive and antithrombotic activity (Rechner, Kroner, 2005). They also have positive effects on the composition and function of the human microflora (Cueva et al., 2010). Phenolic compounds found in wine may prevent or defer the development of gastric diseases caused by inflammation and oxidative stress. Moreover, wine polyphenols acts as prebiotics (Biasi et al., 2014). They and their metabolites interact with epithelial cells, and by controlling the microbial composition of intestines contribute to the maintenance of gastrointestinal health. Nutritional polyphenols also act as substrates for intestinal microflora. (Hervert-Hernandez, 
Goni, 2011). Phenolic compounds have been shown to have positive bactericidal and antioxidant properties, as well as beneficial effects to the health and protection of the organism (Ribéreau-Gayon et al., 2006).

Due to the potential health benefits for human nutrition, studies have significantly increased in recent years, including the development of analytical methods for the determination and measurement of phenolic acids from food and beverages (Robbins, 2003). Analysis of phenolic compounds in grapes and wine may offer particular biomarkers that could help to better evaluate the chemical evolution of grapes during growth and maturation, as well to make progress in the wine authentication by developing and applying new or advanced control methods (Niculescu, 2018). Polyphenols extracted from wine and analysed by $1 \mathrm{H}$ NMR are a good marker for variety, geographical origin, and vintage of wines (Downey, 2016).

The aim of this study was to determine and evaluate chosen properties (total polyphenol content, total flavonoid content, and antioxidant activity) and their mutual correlations in Slovak varietal wines of Muscat type, of various Slovak vineyard areas origin.

\section{MATERIAL AND METHODS}

\section{Chemicals and instruments}

The chemicals used for analysis were: Folin-Ciocalteau reagent, monohydrate of gallic acid p.a., anhydrous natrium carbonate p.a., aluminium chloride p.a., sodium nitrite p.a., sodium hydroxide p.a., 35\%, catechin hydrate $98 \%, 2,2$ diphenyl-1-picrylhydrazyl (DPPH) radical p.a., methanol p.a. All analysed parameters - total polyphenol content, total flavonoid content and antioxidant activity in wines were analysed using UV/VIS spectrophotometry (spectrophotometer Shimadzu UV/VIS-1240, Shimadzu, Japan).

\section{Samples}

Analysed bottled, Slovak varietal wines of Muscat type, namely Moravian Muscat, Muscat Ottonel and Yellow Muscat and their characteristics are described in Table 1. Wine samples of origin in various Slovak vineyard areas were purchased in retail network, to provide that analysed samples of wine would have the same characteristics as wines that are consumed by customers.

Table 1 Characteristics of analysed wine samples

\begin{tabular}{|c|c|c|c|c|c|}
\hline Sample & Variety & Producer & Vineyard area & Vintage & Wine type \\
\hline MM1 & Moravian Muscat & Chateau Topol'čianky & SSWR & 2015 & sweet \\
\hline MM2 & Moravian Muscat & Golguz & LCWR & 2016 & semi sweet \\
\hline MM3 & Moravian Muscat & Vinkova & LCWR & 2016 & semi dry \\
\hline MM4 & Moravian Muscat & Vinkor & NWR & 2017 & dry \\
\hline MM5 & Moravian Muscat & Vinis Winery & SSWR & 2017 & dry \\
\hline MM6 & Moravian Muscat & Chateau Topol'čianky & NWR & 2016 & semi dry \\
\hline MM7 & Moravian Muscat & Sommelier Select & SSWR & 2015 & dry \\
\hline MO1 & Muscat Ottonel & Víno Chudý, s.r.o. & NWR & 2016 & dry \\
\hline $\mathrm{MO} 2$ & Muscat Ottonel & Matyšák & SSWR & 2014 & dry \\
\hline $\mathrm{MO} 3$ & Muscat Ottonel & Chateau Pezinok & LCWR & 2015 & semi sweet \\
\hline MO4 & Muscat Ottonel & Chateau Pezinok & LCWR & 2017 & semi sweet \\
\hline MO5 & Muscat Ottonel & Víno Nichta & NWR & 2017 & semi dry \\
\hline MY1 & Yellow Muscat & Tokaj\&CO, s.r.o. & WRoT & 2016 & semi sweet \\
\hline MY2 & Yellow Muscat & Zlatý strapec - Anna Nagyová & WRoT & 2013 & semi sweet \\
\hline MY3 & Yellow Muscat & J\&J Ostožovič & WRoT & 2015 & semi dry \\
\hline MY4 & Yellow Muscat & Terra Wylak & SSWR & 2017 & semi dry \\
\hline
\end{tabular}

\section{Sample analysis}

\section{Determination of total polyphenol content}

Total polyphenol content (TPC) was evaluated by modified method of Singleton and Rossi (1965). We used 20\% solution of $\mathrm{Na}_{2} \mathrm{CO}_{3}$, Folin-Ciocalteau reagent and distilled water. We pipetted $1 \mathrm{~mL}$ of wine sample into $50 \mathrm{~mL}$ volumetric flask and diluted it with $25 \mathrm{~mL}$ of distilled water. Then, we added $2.5 \mathrm{~mL}$ FolinCiocalteau reagent to diluted mixture, and after 3 minutes, we added $1.5 \mathrm{~mL}$ of $20 \%$ solution of $\mathrm{Na}_{2} \mathrm{CO}_{3}$. Then we filled the sample with distilled water to volume $50 \mathrm{~mL}$, and after mixing, left at the laboratory temperature for 2 hours. We prepared the blank and calibration solutions of gallic acid by the same procedure. We measured absorbance of samples solutions against blank solution at $765 \mathrm{~nm}$. The content of total polyphenols in wines was calculated as amount of gallic acid equivalent (GAE) in mg per 1 litre of wine.

\section{Determination total flavonoid content}

Total flavonoid content (TFC) was evaluated by aluminium chloride method (Chang et al., 2002). We used 5\% solution of $\mathrm{NaNO}_{2}, 10 \%$ solution of $\mathrm{AlCl}_{3}$, solution of $\mathrm{NaOH}$ and distilled water. We added $1 \mathrm{~mL}$ of wine sample and $4 \mathrm{~mL}$ of deionized water to a $10 \mathrm{~mL}$ volumetric flask. $5 \mathrm{~min}$ after adding $0.3 \mathrm{~mL}$ of $5 \%$ sodium nitrite, we added $0.6 \mathrm{~mL}$ of $10 \%$ aluminium chloride. Then we added 2 $\mathrm{mL}$ of sodium hydroxide with concentration 1 mol. $\mathrm{L}^{-1}$ to the reaction mixture after $6 \mathrm{~min}$ incubation. The final volume was immediately made up to $10 \mathrm{~mL}$ with deionized water. We measured absorbance of the solution at $510 \mathrm{~nm}$ against blank solution. The content of total flavonoids in wine samples was calculated as amount of catechin equivalent (CE) in mg per 1 litre of wine.

\section{Determination of antioxidant activity}

Antioxidant activity (AA) was evaluated by method of Brand-Williams $\boldsymbol{e t}$ al. (1995) using of DPPH (2,2-diphenyl-1-picrylhydrazyl) radical. $3.9 \mathrm{~mL}$ of DPPH solution was pipetted into cuvette. We measured absorbance of DPPH solution at $515.6 \mathrm{~nm}$, and then added $0.1 \mathrm{~mL}$ of wine sample, stirred and waited for 10 minutes. After 10 minutes, we measured absorbance at $515.6 \mathrm{~nm}$, and antioxidant effectiveness was expressed as \% inhibition of DPPH (quantitative ability of tested compound to remove in certain period a part of DPPH radical,) and also as Trolox equivalent calculated from calibration curve.

All chemical analyses were performed as four parallels.

\section{Statistical analysis}

MS Excel 2016 and XLSTAT were used to perform statistical analysis. To obtain statistically significant information about the differences between the tested samples, nonparametric Kruskal-Wallis test was conducted (Addinsoft, 2014).

\section{RESULTS AND DISCUSSION}

All studied parameters -total polyphenol content, total flavonoid content and antioxidant activity of muscat type wines are described in Table 2, 3, 4 . 
Table 2 Total polyphenol content, total flavonoid content and antioxidant activity in analysed wines variety Moravian Muscat

\begin{tabular}{lllll}
\hline Sample & $\begin{array}{l}\text { TPC } \\
\left(\mathbf{m g} \text { GAE. } \mathbf{L}^{-\mathbf{1}}\right)\end{array}$ & $\begin{array}{l}\text { TFC } \\
\left(\mathbf{m g} \text { CE. } \mathbf{L}^{-\mathbf{1}}\right)\end{array}$ & $\begin{array}{l}\text { AA } \\
(\boldsymbol{\%} \text { inhib. DPPH) }\end{array}$ & $\begin{array}{l}\text { AA } \\
(\mathbf{m m o l} \text { Trolox. }\end{array}$ \\
\hline MM1 & $468.6 \pm 8.0$ & $64.0 \pm 0.8$ & $67.0 \pm 1.1$ & $0.787 \pm 0.014$ \\
\hline MM2 & $262.1 \pm 5.3$ & $29.9 \pm 0.8$ & $29.8 \pm 0.8$ & $0.339 \pm 0.010$ \\
\hline MM3 & $286.9 \pm 5.3$ & $40.6 \pm 1.1$ & $29.7 \pm 0.9$ & $0.337 \pm 0.011$ \\
\hline MM4 & $300.5 \pm 5.3$ & $29.0 \pm 0.5$ & $32.5 \pm 0.8$ & $0.369 \pm 0.010$ \\
\hline MM5 & $226.8 \pm 2.6$ & $24.8 \pm 0.5$ & $27.9 \pm 0.6$ & $0.317 \pm 0.007$ \\
\hline MM6 & $394.8 \pm 10.7$ & $57.9 \pm 0.5$ & $46.6 \pm 0.8$ & $0.529 \pm 0.010$ \\
\hline MM7 & $371.6 \pm 5.3$ & $53.2 \pm 0.8$ & $37.4 \pm 1.1$ & $0.424 \pm 0.014$ \\
\hline Average & $\mathbf{3 3 0 . 2} \pm \mathbf{8 4 . 8}$ & $\mathbf{4 2 . 8} \pm \mathbf{1 5 . 7}$ & $\mathbf{3 8 . 7} \pm \mathbf{1 4 . 0}$ & $\mathbf{0 . 4 4 3} \pm \mathbf{0 . 1 6 8}$ \\
\hline Legend: MM - Moravian Muscat, MO - Muscat Ottonel, YM - Yellow Muscat, TPC - total polyphenol content, TFC - total flavonoid content, AA -
\end{tabular}

antioxidant activity. Values of TPC, TFC and AA are expressed as arithmetic average \pm standard deviation,

Table 3 Total polyphenol content, total flavonoid content and antioxidant activity in analysed wines variety Muscat Ottonel

\begin{tabular}{|c|c|c|c|c|}
\hline Sample & 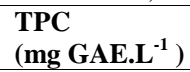 & $\begin{array}{l}\text { TFC } \\
(\mathrm{mg} \mathrm{CE.L}\end{array}$ & $\begin{array}{l}\text { AA } \\
\text { (\% inhib. DPPH) }\end{array}$ & $\begin{array}{l}\text { AA } \\
\left(\mathbf{m m o l} \text { Trolox.L.' }{ }^{-1}\right)\end{array}$ \\
\hline MO1 & $355.2 \pm 5.3$ & $52.4 \pm 0.5$ & $40.7 \pm 1.2$ & $0.461 \pm 0.015$ \\
\hline MO2 & $401.6 \pm 2.6$ & $67.2 \pm 1.3$ & $39.5 \pm 0.7$ & $0.448 \pm 0.009$ \\
\hline MO3 & $316.9 \pm 5.3$ & $47.2 \pm 0.5$ & $33.6 \pm 0.6$ & $0.381 \pm 0.007$ \\
\hline MO4 & $338.8 \pm 2.6$ & $42.2 \pm 0.8$ & $40.1 \pm 0.8$ & $0.454 \pm 0.010$ \\
\hline MO5 & $311.5 \pm 6.0$ & $43.1 \pm 1.3$ & $39.0 \pm 1.0$ & $0.442 \pm 0.012$ \\
\hline Average & $344.8 \pm 36.3$ & $50.4 \pm 10.2$ & $38.6 \pm 2.9$ & $0.437 \pm 0.032$ \\
\hline
\end{tabular}

Legend: MM - Moravian Muscat, MO - Muscat Ottonel, YM - Yellow Muscat, TPC - total polyphenol content, TFC - total flavonoid content, AA antioxidant activity. Values of TPC, TFC and AA are expressed as arithmetic average \pm standard deviation,

Table 4 Total polyphenol content, total flavonoid content and antioxidant activity in analysed wines variety Yellow Muscat

\begin{tabular}{|c|c|c|c|c|}
\hline Sample & $\begin{array}{l}\text { TPC } \\
\left(\mathbf{m g} \text { GAE.L }{ }^{-1}\right)\end{array}$ & $\begin{array}{l}\text { TFC } \\
\left(\mathrm{mg} \mathrm{CE.L^{-1 }}\right)\end{array}$ & $\begin{array}{l}\text { AA } \\
\text { (\% inhib. DPPH) }\end{array}$ & $\begin{array}{l}\text { AA } \\
\left(\mathbf{m m o l} \text { Trolox.L } .^{-1}\right)\end{array}$ \\
\hline MY1 & $513.7 \pm 9.3$ & $99.5 \pm 1.3$ & $57.6 \pm 0.8$ & $0.662 \pm 0.010$ \\
\hline MY2 & $494.8 \pm 10.6$ & $89.6 \pm 1.5$ & $51.4 \pm 0.6$ & $0.586 \pm 0.007$ \\
\hline MY3 & $568.3 \pm 13.3$ & $169.1 \pm 1.3$ & $67.4 \pm 0.6$ & $0.793 \pm 0.007$ \\
\hline MY4 & $308.7 \pm 8.0$ & $43.8 \pm 0.6$ & $43.9 \pm 1.3$ & $0.498 \pm 0.017$ \\
\hline Average & $471.4 \pm 112.8$ & $100.5 \pm 51.8$ & $55.1 \pm 9.9$ & $0.635 \pm 0.125$ \\
\hline
\end{tabular}

antioxidant activity. Values of TPC, TFC and AA are expressed as arithmetic average \pm standard deviation

Total polyphenol content in analysed wines variety Moravian Muscat (MM) ranged from $226.8 \mathrm{mg} \mathrm{GAE} . \mathrm{L}^{-1}$ to $468.6 \mathrm{mg}$ GAE. $\mathrm{L}^{-1}$. Average TPC in all wines variety MM was $330.2 \mathrm{mg} \mathrm{GAE} . \mathrm{L}^{-1}$. Mráz (2017) reported lower average TPC in analysed wines variety $\mathrm{MM}-145.7 \mathrm{mg}$ GAE. $\mathrm{L}^{-1}$. Kývalová (2013) reported higher average value of TPC in analysed Czech wines variety MM - 547.5 mg.GAE. ${ }^{-1}$. Snopek (2019) studied TPC in Czech white wines (including MM) and their changes during storage. He reported that average TPC of wines variety MM was 291.7 GAE.L ${ }^{-1}$. After 12 months, average TPC was 260.75 GAE.L ${ }^{-1}$ These results shows decrease in TPC during storage.

Total polyphenol content in analysed wines variety Muscat Ottonel (MO) ranged from $311.5 \mathrm{mg} \mathrm{GAE} . \mathrm{L}^{-1}$ to $401.6 \mathrm{mg} \mathrm{GAE} . \mathrm{L}^{-1}$. Average content of TPC in all wines variety $\mathrm{MO}$ was $344.8 \mathrm{mg} \mathrm{GAE} . \mathrm{L}^{-1}$. Mitić et al. (2010) reported that average TPC in analysed wines variety MO from Serbia is $252.0 \mathrm{mg}$ GAE. $\mathrm{L}^{-1}$. Lachman et al. (2004) reported lower average TPC in analysed Czech wines variety $\mathrm{MO}-267.0 \mathrm{mg}$ GAE. $\mathrm{L}^{-1}$.

Total polyphenol content in analysed wines variety Yellow Muscat (YM) ranged from $308.7 \mathrm{mg} \mathrm{GAE} . \mathrm{L}^{-1}$ to $568.3 \mathrm{mg} \mathrm{GAE} . \mathrm{L}^{-1}$. Average TPC in all wines variety YM was $471.4 \mathrm{mg} \mathrm{GAE} . \mathrm{L}^{-1}$. Bajčan, et al. (2018) reported lower average TPC in analysed wines variety $\mathrm{YM}-420.5 \mathrm{mg}$ GAE. $\mathrm{L}^{-1}$. Rugovská (2018) reported higher average TPC in wines variety $\mathrm{YM}-525.6 \mathrm{mg}$ GAE. $\mathrm{L}^{-1}$. Lugasi and Hovari (2003) reported that average TPC in wines variety YM from Hungary is $250 \mathrm{mg} \mathrm{GAE} . \mathrm{L}^{-1}$. This is almost half of the value we determined.

Our study shown that average TPC in wines varies between wines of same variety. Bajčan et al. (2017) analysed Slovak white wines variety Welschriesling

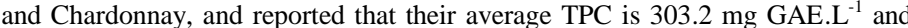
$355.6 \mathrm{mg} \mathrm{GAE} . \mathrm{L}^{-1}$ respectively. Špakovská et al. (2012) analysed Slovak white wines, and reported that their average TPC range from $299 \mathrm{mg} \mathrm{GAE} . \mathrm{L}^{-1}$ to 407 mg GAE. $\mathrm{L}^{-1}$. Staško et al. (2008) reported that average TPC in Slovak white wines (including $\mathrm{MM}$ and MO) is $270 \mathrm{mg} \mathrm{GAE} \cdot \mathrm{L}^{-1}$. More studies of TPC in Slovak white wines (Nedeljak, 2013; Vasková, 2013; Stefanková 2014) reported average TPC in range from $305.6 \mathrm{mg} \mathrm{GAE} . \mathrm{L}^{-1}$ to $365.7 \mathrm{mg}$ GAE. $\mathrm{L}^{-1}$. According to the average value of TPC an order for wines by variety could be as following: Yellow Muscat (471.38 mg GAE.L $\left.{ }^{-1}\right)>$ Muscat Ottonel $(344.8 \mathrm{mg}$ GAE. $\left.\mathrm{L}^{-1}\right)>$ Moravian Muscat (330.2 $\mathrm{mg}$ GAE. $\mathrm{L}^{-1}$ ). According to the average value of TPC an order for wines by vineyard area could be as following: wines from WRoT (525.6 mg GAE. $\left.\mathrm{L}^{-1}\right)>$ wines from SSWR $\left(355.46 \mathrm{mg} \mathrm{GAE} . \mathrm{L}^{-1}\right)>$ wines from NWR (340.5 mg GAE.L $\left.\mathrm{L}^{-1}\right)>$ wines from LCWR (301.18 mg GAE.L $\left.{ }^{1}\right)$. We found statistically significant difference between TPC of Muscat Ottonel and TPC of Yellow Muscat ( $p<0.0001, \alpha=0.05$ ), and between TPC of Musca
Moravian and TPC of Yellow Muscat $(\mathrm{p}<0.0001, \alpha=0.05)$. We found statistically significant difference between TPC of wines from NWR and LCWR, and between TPC of wines from WRoT and LCWR, WRoT and SSWR, and WRoT and NWR $(\mathrm{p}<0.0001, \alpha=0.05)$.

Total flavonoid content (TFC) in analysed wines variety Moravian Muscat ranged from 24.8 to $64.0 \mathrm{mg}$ CE. $\mathrm{L}^{-1}$. Average TFC in all wines variety MM was $42.8 \mathrm{mg}$ CE. $\mathrm{L}^{-1}$. Mráz (2017) reported that average TFC in analysed wines variety MM is $52.0 \mathrm{mg} \mathrm{CE} . \mathrm{L}^{-1}$, which is higher value compared to average value of TFC in our samples. There are not many studies analysing TFC of Moravian Muscat, mainly because it is relatively new variety, mostly grown in Czech Republic and Slovakia.

Total flavonoid content in analysed wines variety Muscat Ottonel ranged from $42.2 \mathrm{mg}$ CE. $\mathrm{L}^{-1}$ to $67.2 \mathrm{mg} \mathrm{CE} . \mathrm{L}^{-1}$. Average TFC in all wines variety MO was 50.4 CE. $\mathrm{L}^{-1}$. Bleiziffer et al. (2017) reported that average TFC in Serbian wines variety $\mathrm{MO}$ is $37.5 \mathrm{mg}$ CE. $\mathrm{L}^{-1}$, which is slightly lower value than ours.

Total flavonoid content in analysed wines variety Yellow Muscat ranged from $43.8 \mathrm{mg}$ CE. $\mathrm{L}^{-1}$ to $169.1 \mathrm{mg} \mathrm{CE} . \mathrm{L}^{-1}$. Average TFC in all wines variety YM was $100.5 \mathrm{mg}$ CE. $\mathrm{L}^{-1}$. Rugovská (2018) reported that average TFC in wines variety YM is $99.1 \mathrm{mg} \mathrm{CE} . \mathrm{L}^{-1}$. Bajčan et al. (2018) reported lower average TFC in analysed wines variety $\mathrm{YM}-83.0 \mathrm{mg}$ CE. $\mathrm{L}^{-1}$.

Our study shown that average TFC in wines varies between wines of same variety. Bajčan $\boldsymbol{e t}$ al. (2017) analysed Slovak white wines variety Welschriesling and Chardonnay, and found out their average TPC is $51.9 \mathrm{mg} \mathrm{CE} . \mathrm{L}^{-1}$ and $60.1 \mathrm{mg}$ CE. $L^{-1}$ respectively.

More studies of TFC in Slovak white wines (Nedeljak, 2013; Vasková, 2013; Štefanková 2014) reported average TFC in range from $38.8 \mathrm{mg} \mathrm{CE}^{-1} \mathrm{~L}^{-1}$ to 67.4 mg CE. $L^{-1}$

According to the average value of TFC an order for wines by variety could be as following: Yellow Muscat $\left(100.5 \mathrm{mg} \mathrm{CE} . \mathrm{L}^{-1}\right)>$ Muscat Ottonel $\left(50.4 \mathrm{mg} \mathrm{CE} . \mathrm{L}^{-1}\right)$ $>$ Moravian Muscat (42.8 mg CE. $\mathrm{L}^{-1}$ ) According to the average value of TFC an order for wines by vineyard region could be as following: wines from WRoT (119.4 mg CE. $\left.\mathrm{L}^{-1}\right)>$ wines from SSWR $\left(50.6 \mathrm{mg} \mathrm{CE} . \mathrm{L}^{-1}\right)>$ wines from VR (45.6 mg CE. $\left.\mathrm{L}^{-1}\right)>$ wines from LCWR (39.9 mg CE. $\left.\mathrm{L}^{-1}\right)$. We found statistically significant difference between TFC of Muscat Ottonel and TFC of Yellow Muscat $(\mathrm{p}<0.0001, \alpha=0.05$ ), and between TFC of Muscat Moravian and TFC of Yellow Muscat $(\mathrm{p}<0.0001, \alpha=0.05)$. We found statistically significant difference between TFC of wines from LCWR and SSWR, and between TFC of wines from WRoT and LCWR, WRoT and SSWR, and WRoT and NWR ( $<$ < $0.0001, \alpha=0.05$ ) 
Antioxidant activity (AA) in analysed wines variety Moravian Muscat ranged from $27.9 \%$ inhib. of DPPH $\left(0.317\right.$ mmol Trolox. $\left.\mathrm{L}^{-1}\right)$ to $67.0 \%$ inhib. of DPPH $\left(0.787\right.$ mmol Trolox. $\left.\mathrm{L}^{-1}\right)$. Average value of AA in all wines variety MM was 38.7 \% inhib. of DPPH $\left(0.443 \mathrm{mmol}\right.$ Trolox. $\left.\mathrm{L}^{-1}\right)$. Křivová, 2016 reported lower average AA in wines variety $\mathrm{MM}-29.95 \%$ inhib. of DPPH.

Antioxidant activity in analysed wines variety Muscat Ottonel ranged from 33.6 $\%$ inhib. of DPPH $\left(0.318 \mathrm{mmol}\right.$ Trolox. $\left.\mathrm{L}^{-1}\right)$ to $40.7 \%$ inhib. of DPPH $(0.461$ mmol Trolox. $\left.\mathrm{L}^{-1}\right)$. Average value of AA in all wines variety $\mathrm{MO}$ was $38.6 \%$ inhib. of DPPH (0.437 mmol Trolox. $\mathrm{L}^{-1)}$. Bleiziffer et al. (2017) reported higher average AA in wines variety $\mathrm{MO}-43.9 \%$ inhib. of DPPH

Antioxidant activity in analysed wines variety Yellow Muscat ranged from 43.9 $\%$ inhib. of DPPH $\left(0.498 \mathrm{mmol}\right.$ Trolox. $\left.\mathrm{L}^{-1}\right)$ to $67.4 \%$ inhib. of DPPH $(0.793$ mmol Trolox. $\left.\mathrm{L}^{-1}\right)$. Average value of AA in all wines variety $\mathrm{YM}$ was $55.1 \%$ inhib. of DPPH $\left(0.635 \mathrm{mmol}\right.$ Trolox. $\left.\mathrm{L}^{-1}\right)$. Bajčan et al. (2018) reported that average AA in analysed wines variety YM is $47.2 \%$ inhib. of DPPH $(0.542$ mmol Trolox. $\left.\mathrm{L}^{-1}\right)$. Rugovská (2018) reported that average AA in wines variety YM is $47.2 \%$ inhib. of DPPH. Eftimová (2016) reported higher average AA in wines variety YM - $63.8 \%$ inhib. of DPPH. Bajčan et al. (2017) analysed Slovak white wines variety Welschriesling and Chardonnay, and found out their average AA is $35.0 \%$ inhib. of DPPH and $43.3 \%$ inhib. of DPPH respectively. More studies of AA in Slovak white wines (Nedeljak, 2013; Vasková, 2013; Štefanková 2014) reported average AA in samples in range from $35.75 \%$ inhib. of DPPH to $50.3 \%$ inhib. of DPPH.

According to the average value of AA an order for wines could be as following: Yellow Muscat (55.1\% inhib. of DPPH) > Moravian Muscat (38.7\% inhib. of $\mathrm{DPPH})>$ Muscat Ottonel (38.6\% inhib. of DPPH). According to the average value of AA an order for wines could be as following: wines from WRoT (58.8 $\%$ inhib. of DPPH) > wines from SSWR (43.14 \% inhib. of DPPH) > wines from NWR (38.94 \% inhib. of DPPH) > wines from LCWR (33.3 \% inhib. of DPPH) We found statistically significant difference between average AA of Moravian Muscat wines and Yellow Muscat wines $(\mathrm{p}<0.0001, \alpha=0.05)$, and statistically significant difference between average AA of Muscat Ottonel wines and Yellow Muscat wines $(\mathrm{p}<0.0001, \alpha=0.05)$. We found statistically significant difference between average AA of wines from LCWR and NWR, and between average AA of wines from WRoT and LCWR, WRoT and SSWR, WRoT and NWR $(p<0.0001, \alpha=0.05)$.

In order to examine the mutual relations between analysed parameters, the linear regressions were attained. The statistical evaluation of the obtained results confirmed strong linear correlation between TPC and TFC ( $r=0.784)$, very strong linear correlation between TPC and AA ( $\mathrm{r}=0.912)$, and strong linear correlation between TFC and AA ( $\mathrm{r}=0.804)$. Based on the results, it can be stated that there are high to very high positive correlations between the individual monitored properties of wines. This is in agreement with other authors (Nedeljak, 2013; Mitić et al., 2010).

Ratio of total flavonoid content and total phenolic content was evaluated. In white wines, flavonoids form less than $20 \%$ of total polyphenol content, in red wines, it is often more than $85 \%$ (Jackson, 2008). Average ratio of TFC and TPC in wines variety Moravian Muscat was $12.95 \%$. Average Ratio of TFC and TPC in wines variety Muscat Ottonel was $14.62 \%$. Average Ratio of TFC and TPC in wines variety Yellow Muscat was $21.32 \%$. Nedeljak (2013) evaluated average ratio of TFC and TPC in wines variety Grüner Veltliner as $18.3 \%$, and average ratio of TFC and TPC in wines variety Chardonnay as $19.46 \%$.

\section{CONCLUSION}

Total phenolic content, total flavonoid content, and antioxidant activity of white wines variety Moravian Muscat, Muscat Ottonel, Yellow Muscat made in Slovak vineyard areas were assessed in the presented study. The highest total phenolic content, total flavonoid content, and highest antioxidant activity were determined in wines variety Yellow Muscat.

Results showed statistically significant differences between total polyphenolic content, total flavonoid content and antioxidant activity between Moravian Muscat and Yellow Muscat, and between Muscat Ottonel and Yellow Muscat Results also showed statistically significant difference between wines from Vineyard region of Tokaj and wines from other vineyard areas. Based on statistical evaluation of our results, we can state that statistically significan correlations were recognised among all 3 analysed parameters (TPC, TFC and AA). Results showed that in comparison with other white Slovak varietal wines of Muscat type, wines variety Yellow Muscat from the wine region of Tokaj have higher content of polyphenolic substances and flavonoids.

The study of phenolic substances in wine is subject to constant development There are many studies regarding antioxidant activity in red wines. Until recently, the prevailing opinion was that the consumption of white wine does not have beneficial effects on the human health, in terms of antioxidant content White wines have also been shown to have antioxidant activity and health benefits.

Acknowledgments: Work was supported by the Slovak Science Foundation VEGA (Grant no. 1/0114/18).
This publication was supported by the Operational program Integrated Infrastructure within the project: Demand- driven research for the sustainable and innovative food, Drive4SIFood 313011V336, cofinanced by the European Regional Development Fund.

\section{REFERENCES}

ADDINSOFT. (2014). XLSTAT, Analyse de données et statistique avec MS Excel. Addinsoft, NY, USA.

BAJČAN, D., ÁRVAY, J., VOLLMANNOVÁ, A., BYSTRICKÁ, J., TREBICHALSKÝ, P., HARANGOZO, L., ŠIMANSKÝ, V. (2017). Antioxidant properties, total phenolic and total flavonoid content of the Slovak white wines Welschriesling and Chardonnay. Potravinárstvo, 11(1). http://dx.doi.org/10.5219/730

BAJČAN, D., VOLLMANNOVÁ, A., ŠNIRC, M., ÁRVAY, J., MEZEY, J, ŠIMANSKÝ, V., TIMORACKÁ, M. (2018). Phenolic compounds and antiradical activity in Tokaj wines. Journal of Microbiology, Biotechnology and Food Sciences, 8(3), 955-959. http://dx.doi.org/10.15414/jmbfs.2018-19.8.3.955959

BIASI, F., DEIANA, M., GUINA, T., GAMBA, P., LEONARDUZZI, G., POLI, G. (2014). Wine consumption and intestinal redox homeostasis. Redox biology, 2, 795-802. https://dx.doi.org/10.1016/j.redox.2014.06.008

BLEIZIFFER, R., SUVAR, S., PODEA, P., MESAROS, C. ... CULEA, M (2017). Blaj white wines characterization. Studia Universitatis Babeș-Bolyai Chemia, 62(3), 123-132. http://dx.doi.org/10.24193/subbchem.2017.3.09

BRAND-WILLIAMS, W., CUVELIER, M. E., BERSET, C. (1995). Use of a free radical method to evaluate antioxidant activity. Lebensmittel Wissenschaft und Technologie, 28, 25-30. http://dx.doi.org/10.1016/s0023-6438(95)80008-5 CUEVA, C., MORENO-ARRIBAS, M. V., MARTÍN-ÁLVAREZ, P. J., BILLS G., VICENTE, M. F., ILIO, A., BARTOLOMÉ, B. (2010). Antimicrobial activity of phenolic acids against commensal, probiotic and pathogenic bacteria. $\begin{array}{llll}\text { Research in } & \text { Microbiology, 372-382. }\end{array}$ http://dx.doi.org/10.1016/j.resmic.2010.04.006

CUEVA, C., GIL-SÁNCHEZ, I., AYUDA-DURÁN, B., GONZÁLEZMANZANO, S., GONZÁLEZ-PARAMÁS, A., SANTOS-BUELGA, C. MORENO-ARRIBAS, M. (2017). An Integrated View of the Effects of Wine Polyphenols and Their Relevant Metabolites on Gut and Host Health. Molecules, 22(1), 99. http://dx.doi.org/10.3390/molecules22010099

DOMINÉ, A., SUPP, E., HOLST, H., JAEGER, H., ASTON, P. (2008). Wine Potsdam, Germany: H.F. Ullmann. ISBN: 978-0841602977

DOWNEY, G. (2016). Wine. Advances in Food Authenticity Testing. Sawston, Cambridge: Woodhead Publishing. ISBN: 978-0-08-100220-9. https://dx.doi.org/10.1016/C2014-0-01962-4

DOWNEY, M.O., DOKOOZLIAN, N.K., KRSTIC, M.P. (2006). Cultura Practice and Environmental Impacts on the Flavonoid Composition of Grapes and Wine: A Review of Recent Research. American Journal of Enology and Viticulture, vol. 57, 257-268

DUMITRIU, G., LUCHIAN, C., COTEA, V., PEINADO, R., LERMA, N., COLIBABA, C., NICOLAUA, M. (2015). Influence of new materials on the chemical composition of Muscat Ottonel wines. Lucrări Stiintifice Seria Horticultură, vol. 58(1), 189-194.

EFTIMOVÁ, Z. (2016). Polyphenols content and antioxidant activity of the Tokaj wines and essences. Diploma thesis. Nitra: Slovak University of Agriculture.

HERVERT-HERNÁNDEZ D., GOÑI I. (2011). Dietary Polyphenols and Human Gut Microbiota: a Review. Food Reviews International, 27:2, 154169. http://dx.doi.org/10.1080/87559129.2010.535233

CHANG, C.C., YANG, M.H., WEN, H.M., CHERN, J.C. (2002) . Estimation of total flavonoid content in propolis by two complementary colourimetric methods. Journal of Food and Drug Analysis, 10(3), 178-182. http://dx.doi.org/10.38212/2224-6614.2748

CHEYNIER, V., COMTE, G., DAVIES, K. M., LATTANZIO, V., MARTENS S. (2013). Plant phenolics: Recent advances on their biosynthesis, genetics, and ecophysiology. Plant Physiology and Biochemistry, 72, 1-20 http://dx.doi.org/10.1016/i.plaphy.2013.05.009

CHEYNIER, V., SCHNEIDER, R., SALMON, J.-M., FULCRAND, H. (2010) Chemistry of Wine. Comprehensive Natural Products II, 1119-1172. http://dx.doi.org/10.1016/b978-008045382-8.00088-5

JACKSON, R. (2008). Wine science: principles and applications. 3rd ed Amsterdam: Elsevier/Academic Press. ISBN 978-012-3736-468.

JIANG, B., ZHANG, Z.-W. (2012). Comparison on Phenolic Compounds and Antioxidant Properties of Cabernet Sauvignon and Merlot Wines from Four Wine Grape-Growing Regions in China. Molecules, 17(8), 8804-8821. http://dx.doi.org/10.3390/molecules 17088804

KABERA, J.N., SEMANA, E., MUSSA, A.R. AND HE, X. (2014). Plant Secondary Metabolites: Biosynthesis, Classification, Function and Pharmacological Properties. Journal of Pharmacy and Pharmacology, 2, 377 392.

KARAOĞLAN, S. N. Y., ÇELIK, Z. D., DARICI, M., KELEBEK, H., ERTEN H., ISÇI, B., CABAROGLU, T. (2015). Effect of terroir on the phenolic 
compounds of Muscat of Bornova wines from 3 different sub-regions of Aegean, $\begin{array}{lllll}\text { Turkey. Bio web of Conferences, } & 02017 .\end{array}$ http://dx.doi.org/10.1051/bioconf/20150502017

KŘIVOVÁ, T. (2016). Selected analytical indicators wines Slovácké subregion as a criterion for their entry into gastronomy. Diploma thesis. Zlín: Tomas Bata University.

KÝVALOVÁ, E. (2013). Determination of Wine Components in Different Varieties of Moravian Wines. Diploma thesis. Zlín: Tomas Bata University.

LACHMAN, J., ŠULC, M., HEJTMÁNKOVÁ, A., PIVEC, V., ORSÁK, M. (2004). Content of polyphenolic antioxidants and trans-resveratrol in grapes of different varieties of grapevine (Vitis vinifera L.). Horticultural Science, 31(No 2), 63-69. http://dx.doi.org/10.17221/3794-hortsci

LUGASI, A., HOVARI, J. (2003). Antioxidant properties of commercial alcoholic and nonalcoholic beverages. Nahrung 47, 79 86. https://dx.doi.org/10.1002/food.200390031

MICHLOVSKÝ, M. (2014). Lexikon chemického složení vína. Rakvice, Czech Republic: Vinselekt Michlovský. ISBN: 9788090531925

MITIĆ, M. N., OBRADOVIĆ, M. V., GRAHOVAC, Z. B., PAVlOViĆ, A. N. (2010). Antioxidant Capacities and Phenolic Levels of Different Varieties of Serbian White Wines. Molecules, 15(3), 2016-2027. http://dx.doi.org/10.3390/molecules15032016

MONAGAS, M., BARTOLOMÉ, B., GÓMEZ-CORDOVÉS, C. (2005).

Updated knowledge about the presence of phenolic compounds in wine. Critical reviews in food science and nutrition, 45(2), 85-118. https://dx.doi.org/10.1080/10408690490911710

MRÁZ, D. (2017) Study of flavonoids in white wines. Diploma thesis. Brno: Mendel University.

NEDELJAK, F. (2013). Polyphenolic compounds and antioxidant activity in white wines - Grüner Veltliner and Chardonnay. Diploma thesis. Nitra: Slovak University of Agriculture.

NICULESCU, V., C., PAUN, N., IONETE, R.-E. (2018). The Evolution of Polyphenols from Grapes to Wines. Grapes and Wines - Advances in Production, Processing, Analysis and Valorization. http://dx.doi.org/10.5772/intechopen.72800

PAVLOUŠEK, P. (2011) Výroba vína u malovinařu. Praha, Czech Republic: Grada. ISBN: 9788024733142

RASOULI, H., FARZAEI, M. H., KHODARAHMI, R. (2017). Polyphenols and their benefits: A review. International Journal of Food Properties, 20(sup2), 1700-1741. https://dx.doi.org/10.1080/10942912.2017.1354017

RECHNER, A. R., KRONER, C. (2005). Anthocyanins and colonic metabolites of dietary polyphenols inhibit platelet function. Thrombosis Research, 116(4), 327-334. http://dx.doi.org/10.1016/j.thromres.2005.01.002

RIBÉREAU-GAYON, P., DUBOURDIEU, D., DONECHE, B, LONVAUD, A (2006). Handbook of Enology, The Microbiology of Wine and Vinifications. Hoboken, New Jersey: Wiley. ISBN: 0471973629

ROBBINS, R. J. (2003). Phenolic acids in foods: an overview of analytical methodology. Journal of agricultural and food chemistry, 51(10), 2866-2887.

ROBINSON, J., HARDING, J. (2015). The Oxford Companion to Wine. Oxford, England: Oxford University Press. ISBN-10: 9780198705383 http://dx.doi.org/10.1093/acref/9780198705383.001.0001

RUGOVSKÁ, A. (2018). Polyphenolic compounds and antioxidant activity in Tokaj wines. Diploma thesis. Nitra: Slovak University of Agriculture.

SACCHI, K.L., BISSON, L., ADAMS, D.O. (2005). A Review of the Effect of Winemaking Techniques on Phenolic Extraction in Red Wines. American Journal of Enology and Viticulture, 56, 197-206.

SANTANA-GÁLVEZ, J., JACOBO-VELÁZQUEZ, D. A. (2018). Classification of Phenolic Compounds. Phenolic Compounds in Food, 3-20.Boca Raton, Florida: CRC Press. http://dx.doi.org/10.1201/9781315120157-1

SINGLETON, V.L., ROSSI, J.A. (1965). Colourimetry of total phenolics with phosphomolybdic-phosphotungstic acid reagents. American Journal of Enology and Viticulture, 16, 14-158.

SNOPEK, L. (2019). Changes of Bioactive Compounds and Sensorially Significant Substances Present in Grape Wines during their Storage. Dissertation thesis. Zlín: Tomas Bata University.

STAŠKO, A., BREZOVÁ, V., MAZÚR, M., ČETÍK, M., KALINÁK, M., GESCHEIDT, G. (2008). A comparative study on the antioxidant properties of Slovakian and Austrian wines. LWT-Food Science and Technology, 41(10), 2126-2135. https://dx.doi.org/10.1016/j.lwt.2007.11.021

STEIDL, R. (2010). Po cestách ke špičkovému vínu. Valtice, Czech Republic Národní vinařské centurm. ISBN: 9788090320185

ŠPAKOVSKÁ, E., MARCINCAK, S., BAČA, M., TUREK, P. (2012) Polyphenolic content and antioxidative activity of wines from the Sobrance wine region. Potravinarstvo. 6. 10.5219/204.

ŠTEFANKOVÁ, T. (2014). Phenolic compounds and antioxidant activity in selected wines - Alibernet and Gewürztraminer. Diploma thesis. Nitra: Slovak university of agriculture.

VASKOVÁ, M. (2013). Polyphenolic compounds and antioxidant activity in white wines - Welschriesling and Müller Thurgau. Diploma thesis. Nitra: Slovak university of agriculture.
VERMERRIS, W., NICHOLSON, R. (2006). Phenolic Compound Biochemistry. eBook ISBN: 978-1-4020-5164-7

VUOLO, M. M., LIMA, V. S., JUNIOR, M. R. M. (2019). Phenolic compounds: structure, classification, and antioxidant power. Bioactive compounds, 33-50. Woodhead Publishing. https://dx.doi.org/10.1016/B978-0-12-814774-0.00002-5 WATERHOUSE, A. L. (2003). Determination of Total Phenolics. Current Protocols in Food Analytical Chemistry. http://dx.doi.org/10.1002/0471142913.fai0101s06 